\title{
THE POLITICS OF NATIONALISM IN THE POLISH-GERMAN BORDERLAND
}

John D. Kulczycki, Belonging to the Nation. Inclusion and Exclusion in the Polish-German Borderlands 19391951, Harvard University Press, Cambridge, MA, 2016, pp. 402.

\begin{abstract}
The review discusses the book by John D. Kulczycki on the politics of national homogenization in the Third Reich and in post-war Poland in the Polish-German borderlands. Kulczycki's book presents a comprehensive and well-structured analysis of the nationalising policies in the entire Polish-German borderland. Referring to the rich literature and primary sources, the author examines the main tenets of the Third Reich and Poland's post-war politics, their local implementation and the similarities and differences between policies in various regions. It is argued that is a very successful and valuable synthesis. The great merit of the book is that it is based on clear and solid theoretical premises.
\end{abstract}

Key words: nation; borderlands; Poland; Germany

\section{POLITYKA NACJONALIZACJI NA POGRANICZU POLSKO-NIEMIECKIM}

Streszczenie

Recenzja omawia książkę Johna D. Kulczyckiego dotyczącą polityki narodowej homogenizacji prowadzoną przez III Rzeszę oraz powojenną Polskę na pograniczu polsko-niemieckim. Książka Kulczyckiego przedstawia całościową i uporządkowa-
KRZYSZTOF JASKUŁOWSKI SWPS Uniwersytet Humanistycznospołeczny, Warszawa E-mail: krzysztofja@interia.pl

CITATION: Jaskułowski, K. (2018). The Politics of Nationalism in the Polish-German Borderland. Sprawy Narodowościowe. Seria nowa, 2018(50). https://doi.org/10.11649/sn.1711

This work was supported by the author's own resources. No competing interests have been declared.

This is an Open Access article distributed under the terms of the Creative Commons Attribution 3.0 PL License (creativecommons.org/licenses/by/3.0/pl/), which permits redistribution, commercial and non-commercial, provided that the article is properly cited. (C) The Author(s) 2018.

Publisher: Institute of Slavic Studies, Polish Academy of Sciences 
ną analizę tej polityki nacjonalizacji. Nawiązując do bogatej literatury i źródeł, autor analizuje główne założenia powojennej polityki III Rzeczy, a także powojennej Polski, ich lokalną realizację oraz podobieństwa i różnice między politykami w różnych regionach. Jest to bardzo udana i wartościowa synteza. Wielką zaletą książki jest to, że opiera się na jasnych i solidnych przesłankach teoretycznych.

Stowa kluczowe: naród; pogranicza; Polska; Niemcy

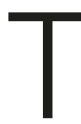

he book by John D. Kulczycki (2016) is an impressive study analysing the policy of national homogenisation in the Third Reich and post-war Poland in the PolishGerman borderlands. The author focuses primarily on the process of incorporation of the so-called Recovered Territories into Poland immediately after 1945. Although the literature on this subject is enormous, it is rather fragmented; i.e., the politics towards the particular territories (Pomerania, Silesia and East Prussia) are usually analysed separately. In contrast, Kulczycki's book presents a comprehensive view of the nationalising policies in the entire Polish-German borderland. Referring to the rich literature and primary sources, the author analyses the main tenets of Poland's post-war politics, its local implementation and the similarities and differences between policies in various regions, and the book is aimed at different national, ethnic and regional groups (e.g., Kashubians, Silesians, Masurians). Unfortunately, the book does not include a bibliography, which could be very useful, considering the enormous amount of literature.

It must be noted that this is a very successful and valuable synthesis. The great merit of the book is that it is based on clear and solid theoretical premises; it draws explicitly on contemporary sociology of nations and nationalism. In contrast to Polish historiography, which often relies on common-sense beliefs about the nation and national identity, Kulczycki problematises taken-for-granted assumptions about nations (e.g., that nations are clearly bounded and easily distinguishable social entities). Kulczycki is not interested in nations that are understood as solid and clearly bounded social groups. Referring to Rogers Brubaker, rather, he asks how the states use the category of the nation to define, classify and mobilise their population. In other words, he sees the nation as a category of practice, not as a category of analysis. Kulczycki argues that we cannot understand-especially in the borderland - the nation as a stable and solid ethnographic or demographic fact that can be precisely measured. The book undermines not only the taken-for-granted assumption about the naturalness of national identities but also the assumption of their strength and primary importance in people's experience. In accordance with recent research, Kulczycki underlines the social significance of national indifference, relative novelty and strangeness of thinking in terms of exclusive national categories (i.e., you must either be a Pole or a German) in the borderlands.

Kulczycki analyses the Polish policy towards the 'Recovered Territories' in a comparative perspective, i.e., against the background of earlier Nazi Germany policy towards the population of Polish territories incorporated into the Third Reich during the Second World War. One of the main findings of the book is that these policies were similar in many respects. Both the Nazis and the Polish communists sought to create nationally homogeneous states. They both assumed that nationality was an objective fact; they believed that an individual could only have one national identity at once; and they perceived minorities as dangerous, because they threatened the nation's purity. Moreover, the post-war Polish government used measures similar to the Nazis': col- 
lective responsibility, mass and forced displacement and expulsions, national verification (in this last case, the Polish communists used the Nazi instruments; this is the German National List, Deutsche Volksliste). Polish politicians believed that earlier Nazi policy justified the use of similar drastic measures. The author also demonstrates the scale of violence against the native population of the 'Recovered Territories'. Thus, The Red Army treated these lands as part of the Third Things; for Soviet soldiers, it was enemy territory populated by Germans whom they were allowed to kill, rape and plunder. Similarly, Poles who came from the east or central Poland without the knowledge of local conditions often treated the members of the native population as hostile Germans, even if they defined themselves as Polish. The local authorities, especially the security apparatus, also demonstrated the lack of understanding of the local conditions, and on a large scale used indiscriminate repression against the native population (utilising the Nazi camp infrastructure).

Kulczycki's book analyses in detail the process of building a homogenous nation state in the 'Recovered Territories'. This process involved brutal ethnic cleansing (forced displacement, deportation to camps, murders) and a more 'subtle' attempt to get rid of any traces of Germanness in the allegedly primordial Polish 'Recovered Territories'. Consequently, for example, the book examines the policy of changing 'German' first names and surnames to be more Polish like or alternating the geographical and topographical names. The author shows that the post-war Polish government assumed that part of the native population was actually Poles who had been Germanised. The right policy was to bring them back to Polishness and help them discover their true national selves. Kulczycki argues that Nazi policy was quite similar: the Nazis believed that some native inhabitants of, for example, Upper Silesia or Masuria who met racist criteria could be Germanised and become full-fledged Germans. It should be noted that these policies were supported by various scientific theories that were to prove the eternal Polishness or Germanness of the relevant lands or populations. Thus, there were many researchers and academics involved in nationalising politics, both in Nazi Germany and in communist Poland. They subordinated cognitive goals with political ones; they saw their role as researchers who developed knowledge; and at the same time, they played a role of nationalist ideologists who provided arguments for state politics of ethnic cleansing. It has to be added that the Catholic Church, as well as opposition politicians and various activists who were far from communism, also supported the politics of re-polonisation.

Kulczycki's book shows the barbarity of both Nazi and communist regimes. Although the latter used violence on a smaller scale, it relied on similar measures and had a similar goal: to create a homogeneous national state, a goal it ultimately achieved. However, as Kulczycki concludes: 'But this success was achieved in part through the unnecessary expulsion, more or less forced departure, and alienation of many individuals who could have been loyal citizens contributing to Poland's reconstruction had these policies and their implementation been different' (Kulczycki, 2016, p. 299). Kulczycki argues that nationalist politics (which relied on the assumptions that nations were clearly bounded entities, that people had stable national identities, etc.) did not correspond to the complex conditions of the borderlands and, consequently, led to arbitrary and barbaric solutions.

To sum up, Kulczycki's work is an impressive and important book. It provides a systematic, comprehensive and detailed analysis of nationalising politics in the Polish-German borderlands. The book is a valuable contribution to our knowledge. It should be of interest not only to specialists and academics but also to anyone interested in modern 
Central European history. The book is written in an accessible language; it reads well and argumentation is supported by vivid examples and quotes that speak to the imagination.

\section{BIBLIOGRAPHY}

Kulczycki, J. D. (2016). Belonging to the nation: Inclusion and exclusion in the Polish-German borderlands 1939-1951. Cambridge, MA: Harvard University Press. https://doi. org/10.4159/9780674969551 